BARTOSZ CZEPIL

Instytut Politologii UO

\title{
Huntingtona koncepcja modernizacji i korupcji a proces „wielkiej zmiany" w Polsce
}

amuel Huntington znany jest polskiemu czytelnikowi przede wszystkim jako twórca koncepcji „zderzenia cywilizacji”, niewiele jednak wiemy o nim jako badaczu, który podejmuje zagadnienie korupcji w kontekście procesów modernizacyjnych. W tym obszarze Huntington zaliczany jest do funkcjonalistów, tzn. takiej szkoły myślenia o korupcji (szczególnie wśród ekonomistów), która upatrywała w niej zjawisko mogące w jakimś stopniu sprzyjać rozwojowi ekonomicznemu lub politycznemu. Napisany przez niego tekst Modernization and corruption będący częścią jego książki Political order in changing societies wpisuje się $\mathrm{w}$ ten paradygmat, a jego teoretycznym manifestem może być następująca teza, jaką stawia autor: „W sensie warunków wzrostu ekonomicznego jedyną rzeczą gorszą od społeczeństwa ze sztywną, nadmiernie scentralizowaną i nieuczciwą biurokracją jest społeczeństwo ze sztywną, nadmiernie scentralizowaną i uczciwą biurokracją". W takim podejściu funkcja korupcji wyrażana jest metaforą „smaru” usprawniającego sztywne i oporne tryby biurokracji.

Warto jednak podkreślić, że Huntington pisał swoją książkę pod koniec lat sześćdziesiątych i od tamtego czasu w obszarze teoretycznej refleksji oraz, co jeszcze ważniejsze, empirycznych badań nad korupcją nastąpiły gruntowne zmiany. Ogólnie rzecz biorąc, można stwierdzić dezaktualizację, a właściwie empiryczną falsyfikację opinii, według których korupcja może przyczyniać się do rozwoju, w szczególności jeśli weźmiemy pod uwagę rozwój ekonomiczny ${ }^{1}$. W czasie gdy Huntington pisał, nie było jeszcze systematycznych badań nad korupcją, brakowało zarówno metodologii badawczej, jak i danych na temat tego zjawiska. W jego tekście pojawiają się raczej ogól-

Przykładowo, ekonomiści Banku Światowego próbując odpowiedzieć na pytanie, czy „smarowanie" przyspiesza koła gospodarki, opierając się na trzech międzynarodowych sondażach (z lat 1996/1997) przeprowadzonych wśród przedsiębiorców, sprawdzili zależności pomiędzy płaceniem łapówek a biurokratycznym nękaniem (bureaucratic harassment). Porównując $\mathrm{w}$ odniesieniu do kilkudziesięciu państw zebrane dane, stwierdzili, że tam gdzie łapówek płaci się więcej i częściej, jednocześnie traci się więcej czasu „na biurokrację”, koszty kapitałowe są wyższe oraz regulacje postrzegane jako bardziej dokuczliwe; D. Kaufman, W. Shang-Jin., Does "Grease Money” Speed up the wheels of commerce?, Washington 1998 [www.worldbank.org/wbi/governance/pdf/grease.pdf, dostęp: 25.03.2009]. 
ne przykłady skorumpowanych przywódców, domysły oparte na „powierzchownych oznakach" (impressionistic evidence), na podstawie których trudno o stwierdzenie ugruntowanych empirycznie prawidłowości. Poważna, to znaczy oparta na analizie systematycznych danych, analiza korupcji zaczęła się dopiero w latach dziewięćdziesiątych, wraz z uznaniem znaczenia sprawnych instytucji dla rozwoju społeczno-ekonomicznego ${ }^{2}$. Międzynarodowej sławy badacz korupcji Robert Klitgaard twierdzi, że okres poprzedzający lata dziewięćdziesiąte, kiedy Huntington pisał o korupcji, to czas kiedy wśród naukowców nie było jeszcze zgody co do jej szkodliwych konsekwencji. Konsens wokół tezy o negatywnych skutkach korupcji zinstytucjonalizował się dopiero w latach dziewięćdziesiątych, kiedy pojawiły się możliwości pomiaru kosztów korupcji³.

Choć z wieloma uogólnieniami, jakie czyni Huntington, możemy się nie zgadzać, na uwagę zasługuje jedna z pierwszych prób powiązania kwestii korupcji z zagadnieniem modernizacji ekonomicznej i politycznej. Jest to szczególnie interesujące, jeśli weźmiemy pod uwagę doświadczenia polskiej transformacji ustrojowej, procesu o charakterze zarówno modernizacyjnym, jak i korupcjogennym. Tu oczywiście warto zadać pytanie, czy niektóre uwagi i konkluzje tego amerykańskiego politologa można odnieść do doświadczeń Polski po roku 1989. Huntington wprawdzie odnosi się przede wszystkim do społeczeństw, które dziś określane są poprawnym politycznie mianem „rozwijających się”, ale poczynione konkluzje wydają się rościć sobie pretensję do statusu socjologicznych lub politologicznych prawidłowości. Sądzę, że niektóre z nich mogą zostać zaaplikowane do procesu „wielkiej zmiany" w Polsce. Interesujące i przydatne analitycznie są tezy Huntingtona dotyczące wpływu procesu modernizacji na korupcję. Szczególnie zmiana na płaszczyźnie aksjologiczno-normatywnej i jej wpływ na definiowanie pewnych zachowań jako korupcyjnych przypomina polskie doświadczenia transformacyjne.

Polska transformacja bez wątpienia była zmianą normatywną, która wymagała od jednostek nowych sposobów działania i definiowania rzeczywistości. Witold Morawski zdefiniował ją jako „proces tworzenia się i krystalizowania nowych reguł $\mathrm{w}$ trzech sferach: polityce, gospodarce i społeczeństwie". . Był to także proces polegający na imitowaniu rozwiązań „zachodnich" poprzez nałożenie nowych konstrukcji instytucjonalnych na

2 Pojawiła się wtedy tzw. nowa ekonomia instytucjonalna, która była przedefiniowaniem klasycznych wyobrażeń o czynnikach wzrostu gospodarczego; A. Kamiński, B. Kamiński, Korupcja rządów. Państwa pokomunistyczne wobec globalizacji, Warszawa 2004, s. 17-23.

3 Zob. R. Klitgaard, Subverting Corruption, „Finance and Development” 2000, nr 2.

4 W. Morawski, Zmiana systemowa w kategoriach instytucjonalnych, Warszawa 1997, s. 12. 
ukształtowany przez kilkadziesiąt lat komunizmu porządek kulturowy ${ }^{5}$. Pojawiły się zupełnie nowe instytucje oraz normy, na podstawie których definiowano dotychczas utrwalone praktyki. Piotr Sztompka pisał o traumie zmiany społecznej, charakteryzującej się między innymi anomicznym stanem równoległego funkcjonowania dwóch sprzecznych syndromów kulturowych - realnego socjalizmu oraz kapitalizmu/demokracji ${ }^{6}$. Mamy więc do czynienia z ukształtowaniem się nowych kryteriów ewaluacji dotychczasowych zachowań ekonomicznych i politycznych. Praktyki, które zinstytucjonalizowały się w życiu codziennym, partyjnym lub, ogólnie rzecz ujmując, publicznym PRL-u, stopniowo uzyskały nowy status etyczny. Obok nepotystycznej kultury „załatwiania” oraz klientelizmu, która w warunkach gospodarki chronicznego deficytu dóbr była funkcjonalną strategią adaptacyjną ${ }^{7}$, pojawia się system redystrybucji zasobów według kryteriów merytorycznych. To, co postrzegane było jako moralnie uzasadnione wsparcie członków własnej rodziny, stopniowo uzyskuje status, posłużmy się kategorią Edwarda Banfielda, „amoralnego familizmu”. Huntington poczynił słuszną uwagę, wskazując, że zakres korupcji jest w dużej mierze efektem zbiorowego, zdeterminowanego aksjologicznie procesu konstruowania znaczeń. Paradoksalnie westernizacja polskiego społeczeństwa jest procesem korupcjogennym, ponieważ nowe standardy życia publicznego są podstawą potępienia postkomunistycznej mentalności korupcyjnej. Niedawno opublikowane, empiryczne studium dyskursu na temat korupcji w polskiej przestrzeni publicznej, pokazuje proces konstruowania problemu korupcji w latach 1989-2004. Autor pracy twierdzi, że nie istnieją jakiekolwiek miarodajne, empiryczne podstawy do stwierdzenia wzrostu obiektywnego poziomu korupcji w ciągu ostatnich kilkunastu lat, wbrew powszechnemu odczuciu tzw. opinii publicznej. Natomiast z pewnością doszło do stopniowej instytucjonalizacji korupcji jako problemu społecznego. Zdefiniowano ją jako zagrożenie dla istotnych wartości publicznych, a kluczowymi siłami generującymi zainteresowanie korupcją oraz penalizację niektórych zachowań jako korupcyjnych były organizacje międzynarodowe.

Dopiero kiedy OECD i Bank Światowy ogłosiły globalną wojnę z korupcją, a Unia Europejska zaczęła uwzględniać ten czynnik w negocja-

Zob. K. Bondyra, Teorie modernizacji wobec polskiej zmiany systemowej, w: Postkomunistyczne transformacje, red. T. Buksiński, Poznań 2004, s. 99.

6 Zob. P. Sztompka, Trauma wielkiej zmiany. Społeczne koszty transformacji, Warszawa 2000, s. 55-60.

7 Na temat funkcjonalnych aspektów układu patron-klient w systemie komunistycznym pisze Jacek Tarkowski. Zobacz szczególnie rozdział drugi pracy: J. Tarkowski, Socjologia świata polityki. Patroni i klienci., t. 2, Warszawa 1994. 
cjach przedakcesyjnych, w Polsce zaczęto ratyfikować międzynarodowe konwencje, zmieniać prawo i budować strategię walki z korupcją. Proces konstruowania społecznego problemu korupcji można łatwo dostrzec i prześledzić, studiując doniesienia prasowe, oficjalne dokumenty, raporty, przeglądając wyniki badań opinii publicznej. Korupcja stała się problemem społecznym w wyniku działań konkretnych aktorów niezależnie od „obiektywnej” skali zagrożenia tym zjawiskiem i jego realnych rozmiarów (których i tak nigdy nikomu nie udało się określić) $)^{8}$.

Wracając do tekstu Huntingtona, zmianom na poziomie świadomości społecznej i politycznej w zakresie definiowania korupcji towarzyszą przeobrażenia strukturalne. Polegają one na pojawianiu się nowych źródeł bogactwa oraz rozrostu regulacyjnych funkcji państwa. Transformacja polskiej gospodarki, w której jednym z istotniejszych wymiarów jest prywatyzacja, stwarza warunki dla nieuczciwego wzbogacenia się. Przy czym, mając wciąż na względzie uwagi Huntingtona, warto zapytać, czy mamy do czynienia z przekształceniem zasobów politycznych w ekonomiczne czy to bogactwo ekonomiczne wykorzystywane jest do celów politycznych? Wydaje się, że w początkowych etapach transformacji nastąpiła konwersja kapitału politycznego na kapitał ekonomiczny, szczególnie wśród przedstawicieli elit politycznych dawnego systemu. Dopiero na pewnym etapie akumulacji kapitału pojawiły się grupy interesów prywatnych zainteresowane korupcyjnym wpływem na politykę (przekształcanie zasobów ekonomicznych w polityczne). Przy czym wydaje się zasadnym stwierdzenie, że zasoby ekonomiczne tych grup mogą być efektem pierwotnego wykorzystania koneksji politycznych dla wzbogacenia się lub mogą pochodzić z uczciwej albo nieuczciwej działalności gospodarczej (aczkolwiek niezwiązanej z wykorzystaniem koneksji politycznych), której owoce są wykorzystywane do zapewnienia sobie korzystnej sytuacji rynkowej lub legislacyjnej.

Proces prywatyzacji przebiegał w warunkach nazwanych przez Jadwigę Staniszkis kapitalizmem politycznym, czyli stanem, w którym „o szansach uformowania kapitału decydowała renta z tytułu obecnej lub niedawnej władzy"9. W kapitalizmie politycznym o sukcesie ekonomicznym decydował dostęp do informacji lub do „odpowiedniej” osoby, uwarunkowany dawnym bądź aktualnym statusem w strukturze władzy. Zajmowanie kluczowych stanowisk politycznych umożliwiało redystrybucję zasobów ekonomicznych oraz tworzenie sieci klientelistycznych. Spółki z udziałem skarbu państwa stanowiły „zaplecze gospodarcze partii politycznych sprawujących władzę:

8 G. Makowski, Korupcja jako problem społeczny, Warszawa 2008, s. 421.

9 J. Staniszkis, Postkomunistyczne państwo: w poszukiwaniu tożsamości, Warszawa 2000, s. 15. 
źródło majątku czy kapitałów, które można transferować do prywatnych spółek, kontrolowanych przez partie oraz zbiór posad (zarządy, rady nadzorcze) dla politycznej klienteli"10.

Huntington uważał, że nowe grupy (warstwy społeczne), jakie wyłaniają się dzięki nowym źródłom bogactwa, poprzez stosowanie korupcji są jednocześnie włączane do systemu politycznego. Korupcja jest więc pewną formą partycypacji politycznej, a przynajmniej zapobiega alienacji tych warstw, co byłoby możliwe w warunkach braku wykrystalizowanych kanałów artykulacji interesów. W przypadku postkomunistycznej Polski taki „funkcjonalistyczny" argument wydaje się nietrafny, ponieważ trudno upatrywać w korupcji formy asymilacji do systemu politycznego. Mieliśmy do czynienia raczej z odwrotnością tego procesu. System polityczny był podporządkowany potrzebom interesów grupowych czy partyjnych, co wyraża się w pojęciu „zawłaszczenia państwa” (state capture). Jestem skłonny uznać, że koszty ekonomiczne, polityczne oraz kulturowe (mam na myśli erozję legitymizacji dla chwiejnego i młodego systemu demokratycznego) wynikające z tego typu korupcji, są wyższe niż ewentualne zyski z inkluzji tych korupcjogennych grup. Szczególnie jeśli weźmiemy pod uwagę fakt, że z początkiem lat dziewięćdziesiątych następuje eksplozja różnego rodzaju organizacji politycznych i społecznych, które stanowią instytucjonalną płaszczyznę formułowania oczekiwań pod adresem systemu politycznego. Argument o korupcji jako instytucji inkluzji politycznej, substytucie reformy lub rewolucji, może być trafny w odniesieniu do reżimów niedemokratycznych i wydaje się, że w jakimś stopniu sieci patronacko-klientelistyczne w systemach komunistycznych pełniły tego typu funkcję $e^{11}$.

Warto poświęcić także uwagę kwestii regulacji rządowych jako źródła korupcji. Huntington niewiele różni się pod tym względem od neoliberalnie zorientowanych strategów i organizacji walczących z korupcją. Strategia ,jak najmniej rządu” promująca deregulację, prywatyzację, likwidację rozbudowanego systemu uznaniowości państwowej jako antykorupcyjne recepty, opiera się na założeniu o korupcjogennym wpływie rozbudowanego sektora publicznego ${ }^{12}$. W komunistycznej Polsce całkowitemu upolitycznieniu wszystkich płaszczyzn życia społecznego towarzyszyła dyskrecjonalna,

10 M. Jarosz, Okazja czyni złodzieja, czyli proces transformacji i prywatyzacji w Polsce, w: Korupcja. Oblicza, uwarunkowania, przeciwdziałanie, red. A. Dylus, A. Rudowski, M. Zaborski., WrocławWarszawa-Kraków 2006, s. 66.

11 Zob. J. Tarkowski, dz. cyt.

12 Zob. Program monitoringu i akcesji do Unii Europejskiej. Korupcja i polityka antykorupcyjna. Open Society Institute, 2002; wydanie w polskiej wersji językowej w tłumaczeniu Barbary Gadomskiej, Warszawa, s. 28-29. 
zmonopolizowana władza nomenklatury, która doprowadziła do instytucjonalizacji korupcji. Proces modernizacji polskiego społeczeństwa polegał między innymi na zawężeniu funkcji państwa oraz uwolnieniu gospodarki w szczególności od wszechmocnej władzy urzędnika państwowego (oczywiście nie oznacza to, że urzędnicy zostali jej całkowicie pozbawieni). Pod tym względem możemy uznać, że postkomunistyczna modernizacja nie polegała na rozszerzaniu funkcji państwa, ale na ich redukcji, co wraz z poprawą dostępu do dóbr pierwszego rzędu przyczyniło się do wyeliminowania drobnej korupcji „dnia codziennego”. Ale sam proces wycofywania się państwa z gospodarki, wyrażający się choćby w prywatyzacji, może być korupcjogenny, tak jak korupcjogenna jest „niedokończona prywatyzacja” polegająca na istnieniu liczny spółek skarbu państwa obsadzanych według tzw. klucza politycznego. Uważam, że założenie Huntingtona o korupcjogennym wpływie regulacji rządowych jest trafne, jednak modernizacja może przebiegać również w kierunku odwrotnym tzn. ograniczeniu funkcji państwa.

Konkluzją jest stwierdzenie, że w porównaniu do korupcjogennej roli scentralizowanego systemu polityczno-ekonomicznego Polski realnego socjalizmu, modernizacja (transformacja) stworzyła warunki do korupcji w innych obszarach. Zredukowaniu korupcji na linii urzędnik niższego szczebla przeciętny obywatel, towarzyszył wzrost korupcyjnej wymiany pomiędzy przedstawicielami świata biznesu a urzędnikami z wyższych szczebli hierarchii władzy. Na poziomie dyskursu, który nazwałbym „zdroworozsądkowym", ta zmiana punktów ciężkości wyraża się w zastąpieniu stwierdzenia „kto nie smaruje, ten nie jedzie” innym symptomatycznym zwrotem mówiącym, że „pierwszy milion trzeba ukraść”. Pierwszy zwrot jest dziedzictwem konfrontacji z ociężałą, zamkniętą i sztywną biurokracją Polskiej Republiki Ludowej, kiedy „smar” był podstawowym sposobem pozyskiwania społecznie cenionych zasobów. Zastanawia mnie, ile planów gospodarczych nie zostałoby zrealizowanych, gdyby urzędnicy tamtego okresu byli uczciwi wobec irracjonalnych zasad gospodarki centralnie nakazowo-rozdzielczej. W odniesieniu do systemu centralnie planowanej gospodarki przywołana na początku teza Huntigtona, według której nieuczciwość wobec zasad sztywnej i zcentralizowanej biurokracji może okazać się funkcjonalna, wydaje się aktualna. Drugi zwrot jest symptomem nadejścia nowych, kapitalistycznych czasów, kiedy w warunkach deficytu kapitału prywatnego przy jednoczesnej presji na bogacenie się, pojawiła się „kultura cwaniactwa” będąca wynaturzoną formą amerykańskiego mitu „od pucybuta do milionera". Jednocześnie lata dziewięćdziesiąte to okres kształtowania się dyskursu antykorupcyjnego, który budowany był na opozycji i krytyce wobec „kultury cwaniactwa" oraz promowaniu nowej propozycji ustrojowej, jaką miała być 


\section{RP}

IV RP. W tym kontekście możemy powiedzieć, że korupcja oraz jej obecność w dyskursie publicznym może być czynnikiem rozwoju politycznego. Rozwój ten niekoniecznie musi wyrażać się w zwycięstwie partii politycznych, które sztandarowym hasłem wyborczym czynią walkę z korupcją. Ważniejsze jest pojawienie się nowej płaszczyzny rywalizacji międzypartyjnej polegającej na uznaniu fundamentalnego znaczenia standardów etycznych $\mathrm{w}$ pełnieniu funkcji publicznych. Wtedy „czystość” sprawowania władzy jest permanentnie monitorowana, transparencja staje się nadrzędną wartością, a elita władzy ponosi koszty polityczne za sprzeniewierzenie się zasadzie oddzielenia interesów prywatnych od interesu publicznego. 